\title{
A woman in academia: ... and what about the children?
}

by Livia Holden with the collaboration of Marius, Ethan, Luna, and Taima Holden; drawings by Lian Holden

Chapter submitted for the manuscript titled Metaphors, manifestos, angst and agency: Listening to and learning from women's lived experience in academe edited by Black and Gravis.

\section{Biography}

Livia Holden is Senior Researcher at Oxford university and full professor at Padua university. She directs Cultural Expertise in Europe: What is it useful for? funded by the European Research Council. Among her publications: Hindu Divorce, Cultural Expertise and Litigation, and Legal Pluralism and Governance in South Asia and Diasporas.

\begin{abstract}
I have been academician in three continents and throughout six countries. The reoccurring question was: "... and what about the children?" People wanted to know what my children think about the life that we lead. I respond for the first time through a polyphonic narrative to share our experience as a family. I argue that the patriarchal expectations that negatively impacted on my life as mother and academician are linked with class. Hence, the apparent paradox between outdated gender expectations in the European middle class context, and the uneventful combination of motherhood and career among the upper class in Pakistan.
\end{abstract}

\section{Keywords}

Gender roles, family-making, Pakistan, academia, gender policies

\section{Introduction ${ }^{1}$}

I left Italy about thirty years ago after a scholarship abroad opened an intellectual horizon and professional opportunities that longed for. When it happened I did not fully realize the extent and the reasons of this change. It just felt natural to go where I could fulfill my dreams. I have been an anthropologist, teacher, and consultant in six countries throughout three different continents. I have carried out research for more than twenty years in India and in Pakistan. My most recent assignments before coming back to Italy have been in Australia and in Pakistan. I travelled with my partner at the beginning, and then with our four children. I have also extensively travelled on my own for conferences, and short assignments to places where I was not

\footnotetext{
${ }^{1}$ Heartfelt thanks to Susan F. Hirsch and Emma Varley for their comments and encouragements during the incertitude and concern that I experienced when writing this paper. Flaws are only mine.
} 
allowed to bring family. This was not easy and straightforward as it might sound here but it is the part of my life I can talk about openly.

Whilst parenthood has been, for my partner and I, one of the leading components during the unfolding of our life together, I have almost immediately learnt to conceal motherhood because of its impact on my career. I have also learnt to protect my family from the curiosity that it very often generates. During all this time the reoccurring question has been: “... and what about the children?". People want to know what my children think of the life we lead. The expectation is that we have been longing to return "home" and settle in a more conventional routine after thirty years abroad. For the first time I will respond with a polyphonic and autobiographic paper that includes drawings, a poem and personal accounts by my children and partner. My aim is to provide the context of my choices revolving around career and motherhood, which I suggest, can be combined in various ways. The greatest obstacles for me have not come from motherhood but from the social expectations attached to it.

\section{Motherhood and career}

My most significant professional assignments have coincided with my pregnancies and early parenthood. Whilst I was overjoyed by the anticipation of motherhood I had to confront mainstream social conventions that were expecting me to put my career on the backburner. After I naively announced that I was expecting my first child, Ethan, my post-graduate supervisor in Paris stopped responding to my emails. Perhaps only because I did not tell anyone else that I was pregnant, I was offered my first significant teaching appointment in Paris a few months later, which I carried out until delivery without anyone noticing. However, I wished to continue with a $\mathrm{PhD}$ in law and society in South Asia. Since my post-graduate supervisor disappeared the way he did, Marius, my partner in life and in profession, who I see as the veritable orchestrator of my career, decided that I should go for a $\mathrm{PhD}$ in the United Kingdom.

During my PhD in London I again shared the news with my supervisor that I was pregnant with my second child, Luna. Silence ensued once again, and when she was born, I was reminded not to let her distract me. At that time I was writing my thesis with Luna's crib hanging from underneath my desk. I had learnt my lesson with my third child, Lian, who was born without anyone knowing in my professional circle. At that very same time, I was finishing my $\mathrm{PhD}$ and co-parenting Ethan and Luna, who were respectively 5 years and 18 months old. Almost as a materialization of the old saying "children come with bread on their arms" I was offered a research position in Berlin. Had I told my future employer in Berlin that I had just delivered, I was sure that I would have never gotten that position. In fact, bidding me farewell my supervisor in London, told me: "Good luck. You will soon be taken by your familylife and forget all this".

In Germany, the legislation allows parents to take parental leave. I only availed this right two years from the start of my new position because I felt I should not endanger the implementation of my director's project. For once, I was responding to social expectations. I had also not asked for maternity leave - as I easily could have 
- shortly after taking up my position one year earlier. It was when I was pregnant with my fourth child, Taima, that things started to turn sour. This time I was simply too exhausted to go to work until the delivery day and I asked for maternity leave. I had just signed a contract for the publication of my first monograph which none of my coteamers had secured yet. The university syndicate alerted me that at six months after delivery my employer could fire me. This is exactly what happened and we left Europe. I accepted a visiting position in Australia where I could write, publish my book and rear my children in the beautiful environment of the Gold Cost. After Australia, we chose Lahore over Paris and this is where most of our children's memories were formed.

\section{From Gold Cost to Pakistan}

Pakistan. It certainly isn't a country with a shining reputation. At the Gold Coast school together with cheerful learning, the kids were also given some prejudices, which we were trying hard to fight against at home. In class, my eldest was read a fictional story about an Australian girl returning to Afghanistan to be forced into marriage. His imagination was enticed: "Isn't Pakistan where the Talibans are and where girls are married off to old men? Will we have to carry guns and walk around with bodyguards?" The kids were whipped up into a frenzy of questions, and they started madly dashing around the house. They felt the excitement of those special moments, when one realizes that life is about to do a complete flip and change into another unknown and unimaginable direction. I certainly knew we were in for a big change, but I could not foresee just how big. Our imagination went wild and a seed of eagerness germinated into a plant of excitement. I was already looking around me, silently contemplating what I would take and what I would leave behind. But how can you plan moving to a place like Pakistan?

And what did we have to say goodbye to! Our life in Australia was not a bed of roses yet the natural surrounding was by then part of our everyday life. I would dearly miss the nocturnal fragrance of murraya, the Australian variety of jasmine, and the precipitated steps of the possums on the roof and their jumps and fights in the night. The early morning din of cockatoos and parrots, the blue tongue lizard looking at me from down in the foliage of "our" rainforest corner. I would certainly miss cycling on the seaside, gardening until dark after a long day spent writing, spotting stingrays in the Broadwater, bathing with the colorful fish the tide had swept into the lagoon, looking at my girls mindlessly going to school in black skirts and white socks, bush-walking in the late evening hand in hand with my two smaller kids, being scared by the flying foxes, the bats of Australia's night sky, discovering with amazement yet another family of glow-worms, and pouring warm coffee in our cold steel cups while star watching in the night. How could I ever leave all this?

I had given my availability for a position as assistant professor in tenure track in Pakistan. The offer said, very graciously, that it was the outcome of a unanimous decision. "Basically you can either come for a visit or for a permanent position. It is your choice... You can teach and do research on whatever you want.... I will not ask 
you many questions because my colleagues will ask you again and again the same questions anyway.... The salary is not competitive for western standards. You cannot pay a mortgage in Europe, but you will have enough to live here very comfortably with your family." The words of my future head of department started echoing in my mind while I still refused to realize where we were heading.

Marius was already googling, frenetically collecting information, pictures of the campus, jokingly scrutinizing the CVs of my future colleagues (most of them holding degrees from prestigious universities), and contently submitting all the pieces of information to me with a slightly teasing expression on his face: "Look what you've done this time!" His greatest piece of evidence to bring his point home was an all men group photo of the faculty council sitting in a bare room around three tables put together and looking intently at the camera. But he had also found pictures of a rich library and the guesthouse. We were already figuring out to study Urdu on those books with shining spines and trying to estimate the size of the rooms. The heavy furniture looked solid but a bit depressive and the dark curtains appeared to block any light from entering, immense double beds, and a large 1960s' style kitchen. Not that it was really of any importance. We had been told we would move to an unfurnished flat on campus after two weeks and I was already dreaming of furnishing it with the very nice pieces I had always admired during our fieldworks in South Asia but never could buy because we were always on the move.

Indeed, after four years in Australia, we were meant to go back to Paris. I had been in touch with my former colleagues and friends in Paris almost daily in the last year and was writing an exciting project about law and governance in India. We had been finally awarded funds and I had been proposed a three year full time contract that was the most promising platform for a permanent job as a researcher in Paris: the dream of my life ten years earlier. But naturally a lot had happened in between: four children and much more. I was utterly dismayed at a salary offer that could barely support a single person in Paris. The inner rebellion that had always characterized my life was still there and Pakistan probably had not come without a reason: I was unconsciously searching for a way out. I desperately needed to believe that there was a way to both support my family and continue at the same time with field research.

It is amusing how clearly I remember every piece of furniture we had in our Queensland house. The bamboo bed that we had been searching for years and by then recently acquired was one of my favorites but this had to stay. I decided that I would take the chest-drawer and the small desk that I had bought for almost nothing on an eBay auction. Marius wanted to bring his piano and the children wanted their toys. Perhaps fearing that I may not take things seriously I was asked to sign a promise of contract. It was on the eve of the Sri Lankan cricket team bombing in Lahore. On the $3^{\text {rd }}$ March 2009, 12 gunmen attacked a bus that carried the Sri Lankan cricket team to Lahore. Six policemen that were escorting them were killed and eight cricketers were injured. I woke Marius up to tell him that we had been crazy to even think about leaving Australia. I would never move anywhere else: not even to Paris, let alone to Pakistan. The news had not yet sunk in properly that I received an email from my future head: 
'Dear Livia, I hope you are well. I am writing to allay concerns that you must have after yesterday's suicide blast in Lahore. It has shaken all of us in Pakistan but let me reiterate that on a personal level I do not feel under threat. All the attacks that have happened so far have been targeted at the security forces. Nothing has been focused at foreigners or the general public. It is still worrying and from far away it looks worse than it is. But let me share with you that recently I too have - on occasion - wondered about security here. But when I have evaluated the situation carefully I have found that the threat of a suicide attack is far less than being run over by a car in any country. It is entirely normal for you to feel concerned and the decision must be yours. But as a colleague I will tell you that I don't feel you are at risk here. I would be happy to speak to you in greater detail if you so desire. In the meantime we are all greatly looking forward to your arrival here. Do let me know also what age your children are - my own daughter is 4 and goes to a good school nearby. If you need I can check for you on vacancies here as well.'

Soon thereafter, almost joking, I was again checking that the children and Marius were still content about moving to Pakistan. They were coming from a visit to a bigger house that we were dreaming of renting: in front of the ocean, with a garden, and a barbecue area. Wet and tanned by the Australian sun, their eyes were shining, bare foot, and looking at me with a questioning gaze: "This is another one of your ideas mum.... Don't tell us you really want to go to Pakistan?"

We went to prepare the dough for our homemade pizza. My two girls and I happily and vigorously kneaded the dough and put it aside to rise. I went outside in the backyard to hang the laundry. A huge toad was croaking in the corner and I was pleased in thinking that this was a good sign, indicating the health of our garden. The bats were flapping their wings in the upper foliage of the front yard pine that day. We always thought the pine would uproot the tiny old house that we were living in. I was thinking that I would better put on my boots if I wanted to stay outside because I heard of a neighbor who almost died just the day before. Snakes were always lurking around. But the telephone was ringing. I knew it was from Pakistan and I could already see our-selves there.

\section{From Marius' diary}

Since that long distance phone interview with Pakistan, a feeling of excitement and apprehension grew in me. I was aware that Livia was looking for a way to expand and develop our research while also responding to the needs of our family. We both wished to share our interest for the life and culture of South Asia with our children. And we had grown skeptical of the short stints of fieldwork to which much anthropology has been relying on. There were worries too: money, security and our children's education. 


\section{Lahore (by Luna Holden)}

Pakistan is a country in Southern Asia that sits snugly between Afghanistan and India. My mother, an anthropologist, and my father, a filmmaker, carried out their research in Pakistan. As a result, we, all six of us, lived there for six years. The earliest memory I have of going to Pakistan was while we were still living on the sunny coast of Australia. At the time, I hadn't the slightest idea of what sort of country my mother was talking about. However, I do recall thinking that the place had a peculiar name. I had to tell my classmates and teachers of our new destination immediately. Contrary to my expectations, I received unenthusiastic responses such as "That's nice Luna" and "Send me a post card when you get there". We also got a class about the "free countries of the world" among which Pakistan was not listed and the teacher read a paper about living in Afghanistan, a war torn country.

When we did arrive, postcards were not exactly on my mind; whereas exploring the campus where my mother worked was. There was a park, with a playground, a pen of prepossessing peacocks, large ponds with ducks and upon further investigation, snakes and a couple of nocturnal huge lizards. What was not so appealing of the University was the "moat", as we started to call it. The university, with its manicured green parks, charming animals, modern science centres and classrooms, was surrounded by a black ditch filled with sewer waste. We came to know later that what we called the moat had been already suggestively nicknamed "Chanel No.5".

Travelling in Pakistan was among the most memorable and interesting experiences I ever had. Multan, with its marble floored guesthouse and Peshawar, infamous for its black-market, a highlight for my older brother, Ethan. Lian and Taima, instead, adored the buffets where we happily helped ourselves into the largest breakfast we have ever had. Islamabad, the verdant capital city, Hyderabad, which was suffering from catastrophic floods, Chilas, a rocky town on the Karakorum Highway with its houses built with clay and stone, Shimshal, a valley that did not have any road until ten years ago, and the many smaller towns and villages that our father drove us to.

We visited the majority of these places due to our mother's work and my father's filming which involved interviewing police, lady judges and visiting universities to carry out lectures or attend meetings. If there were to be a "behind the scenes" of the Lady Judges of Pakistan documentary it would mainly consist of us four, drinking large glasses of cool Coca Cola and snacking on chips while my mother inquired about the issues that lady judges would face in their careers. During one of our visits in Peshawar, my mother was talking with one such judge. Since my siblings and I were all present, the subject of family turned up and she said, "You are lucky to be able to bring your family to work with you, we cannot do this". Ethan will always remember the display of guns that he was offered to try during our visits in Peshawar. I remember the winter of 2011 when we were staying at the house of a lady judge in 
Balochistan. She had two young sons that we played cricket with. I have become good friends with her niece, with whom I used to swap jewellery and dresses.

At the close of almost four years in Lahore a completely different area of Pakistan opened up. My mother was offered a position in a dry and mountainous northern area named Gligit Baltistan. Opposed to the constant humidity of Lahore and Islamabad, Gilgit, with its thin atmosphere and chilling winds causes days to be hot and nights to be contrastingly cold: the Martian climate.

\section{Gilgit Baltistan (by Taima Holden)}

We, the Holdens, were six on a Pajero spaceship approaching the planet Karakorum. There was a checkpoint just in front of us. We landed the spaceship. One of the guards had a big moustache and came to us in a space suit. He boarded and asked, "Can I see your passports?" Daddy agreed "Yes" The guard looked at us content: "baby... baby... baby... no baby, no baby and no baby" counted the guard ("baby" is a common appellation used for children in Pakistan). "Hmm... I see that you are not citizens, we are told not to let foreigners pass," stated the guard with a serious face. "What! We could pass last time!" replied mommy. "Well, now you can't" the guard insisted. Mommy extracted her cubephone051 from her pocket but to our dismay there was no signal. The guard looked again at us and then looked at the endless space and stars in the sky and said "Hmm ... there was a mistake, you can go" with a fake smile on his face. We started the engine and lifted off.

We landed on a desolate landscape of barren mountains. It was too quiet. I thought: "Anyway, we came here just for picking up a parcel and we won't stay long". There were no shops and no people. We had pistols, so we could defend ourselves. There was a package on the floor and our parcel, which I picked it up. "We should leave soon," I said, because we were vulnerable. When we were walking back to our spaceship, I accidentally stepped on a glass bottle and crushed it. The sound echoed and then I heard a screech. "Run!" my older sister Lian, yelled. We ran but when I looked behind I saw.... millions of fungi running at us. They had no eyes but they had mouths with sharp teeth. We threw our reserve chips packets that would slow some of them down. "Now what do we eat when we leave!?" I exclaimed. "Don't worry, I will send a distress signal for a fast delivery pizza." reassured daddy. He then pulled out a remote control and pressed the "open" button. The spaceship door slid, then there was a very loud thump and a crash. The sky was closing! I looked behind me and saw in the distance a huge fungus crashing buildings of the abandoned market place to get through. The mountains were lighted with the festival's fires. We rushed into the spaceship. Daddy started the engine and we lifted off. "Phew!!!" I let out in relief but then I noticed a fluffy kind of hair as it landed on a flower, which we kept in the space ship as a memory that grew into a fierce cat. Three years were over since we landed for the first time in Gilgit. It felt like dashing through the stars - as in that story about ghosts, witches, foxes, and leopards sitting in the dark around the fire. 


\section{Out of Pakistan (by Luna Holden)}

Seven long years had passed and our suitcases were being inspected one by one at the Islamabad airport. A few months ago we had extracted every piece of furniture from our sandcastle-like house in Northern Pakistan; we brought most, sold others and gifted several. The wardrobes and cabinets that we chose to bring were loaded into Pakistan's colourfully decorated trucks, which bumbled along the Karakorum destined to be shipped off to Italy. We were determined to haul as much as possible, even though mother was warning us of the very possible risk that our valuables would be confiscated. My parents were worried about their documentary footage and our family films, still in tape form. I watched the guards proceed with their inspection. "What about this necklace?" - "Just a gift from my aunt." I responded thinking about the lady judge from Balochistan. Answering with more personal details would reduce the danger of further questions. Strangely it was a plastic jar full of worthless coins that distracted most of the officers. The bags were zipped with effort due to the bulk they contained and we walked towards our gate with satisfaction.

\section{After Pakistan (by Marius Holden)}

As of now, it is still difficult for me to draw a balanced outline of those seven years in Pakistan. Nevertheless, I will try to trace out some reflection about our experience in Pakistan as parents and academics. My long term expectations at that time, were to expand and develop what I had so far done in ethnographic filmmaking, improving my Hindi, learning Urdu and deepening the study of Hindustani music while travelling with my family throughout Pakistan. The colossal hubris of these goals were adjusted by the priority that I usually try to accord to Livia and our family's needs. During our time in Pakistan the definition of our roles grew more pronounced and interestingly, our different perception of the social environment too. While Livia took financial and professional responsibilities upon herself, she became increasingly concerned, whilst I grew increasingly optimistic. My focus became the day-to-day achievements of our children's education and the general enjoyment of family life in travels, food and entertainment. Whether this was due to the embodiment of our social roles or to the ripening of our individual predisposition under the scorching sun of Punjab, this divergence determined the kind of complementarity of our ethnographic research.

We could in most cases associate data collection with the pleasure of travel and discovery along with our children and as a family. However, at the stage of film and article production, Livia's concerns were toward the audience. Whatever was ambiguous, side-looped, self-contradictory and marginal even if visually captivating, was doomed to fall on the digital editorial floor. The outcome for Livia had to be profitable in terms of time and energy investment. I tended instead to believe that oddities and self-reflexive anecdotes would convey the unique experience that we were living in. I was worried that excessive efforts to bridge our experience for the 
understanding of our audience might denaturalize the sense of what we were doing. But with hindsight I see now that the privilege and advantage of being a man and a foreigner in a patriarchal post-colonial setting might have started to seep under my skin.

\section{Europe (by Luna Holden)}

Arriving in Europe after many years was a peculiar sensation. Apart from our oldest brother, my siblings and I had very vague and little memories of Europe. As a result, the experience has been new and refreshing: hot water, uninterrupted electricity, and speedy Internet. One would assume that, although living in Pakistan was an exciting adventure returning to Italy would be more comforting: we would reunite with old friends, visit our previous school and greet everyone in the neighbourhood. However, neither of my siblings or myself had ever lived there before. In reality we never did return to Italy. In fact just as one who has lived their entire life in one place would find it difficult to imagine a life moving from country to country, I could never envision living my entire life in one town. Adaptation has always been a welcome friend and home is wherever we make it.

\section{Conclusions}

This paper is different from all the other papers I have written so far. As a polyphonic autobiography it cannot but being discontinuous: lives don't have a clear trajectory that can be organized into a tight little story. It does not pretend to be representative of anything else than our experience. However, what happened during the writing of this article is significant. When I started to write at the end of 2016 we had just come back to Italy. I had been invited back to the country where I was born and offered full professorship with tenure. All came back with revenge: the academic patronage and the male oriented expectations that I had subconsciously run away from thirty years ago. $^{2}$ The expectations were that coming from Pakistan with a large family I could not but be grateful for the opportunity of stability. No matter my successful career abroad and the important research funds that I was carrying with me. Little did they know that my experience in Pakistan, albeit difficult on many points, had been uneventful for what concerns social expectations linked to motherhood. Whilst in Pakistan as a privileged European woman associated with the upper class, I could happily combine family life and career; in Europe, as a middle-class female academic, I was expected to conform to conservative gender roles for the supposed wellbeing of my children. Motherhood had been in my early career the argument that was brandished as a "natural" obstacle. Now motherhood again was used to undermine my position of research leader. “.... And what about the children?" The same well meant question reoccurs again and again. This time I was almost convinced that for the wellbeing of

\footnotetext{
${ }^{2}$ There is rich a literature describing the patronage that affects Italian university. See among others Gardini (2009) Shore (1989).
} 
my children I should give up. But, perhaps surprisingly for some, Marius and children told me that I should not. From the time I started writing this article and now that I am closer to its publication, I have decided that I am not yet ready to give up. Yet by refusing to give up I am challenging patriarchal family-making practices that still expect women to choose between family and work. ${ }^{3}$ I see now how privileged I have been to combine professional and family life even though often it felt as to be awaiting for the big storm.

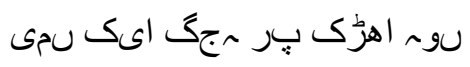

I am standing in one place (by Ethan Holden)

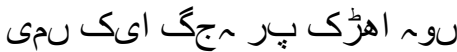

$$
\begin{aligned}
& \text { I am standing in one place }
\end{aligned}
$$

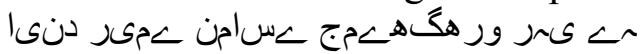

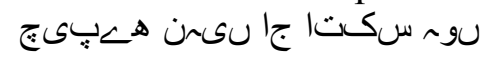

$$
\begin{aligned}
& \text { I can't go back } \\
& \text { טى وى }
\end{aligned}
$$
So that, when night comes, I can light a warm fire

\section{Figures}

Fig.1 - Gold Coast (ink drawing by Lian Neha Holden)

Fig. 2 - Lahore (ink drawing by Lian Neha Holden)

Fig. 3 - Gilgit Baltistan (ink drawing by Lian Neha Holden)

\section{Bibliography}

\footnotetext{
${ }^{3}$ See among others Krauser (2005).
} 
Gardini, N. (2009). I Baroni. Come e perché sono fuggito dall'università italiana. Milano, Feltrinelli.

Krauser, E. (2005). Encounters with the "peasant": Memory work, masculinity, and low fertility in Italy. American Ethnologist, 32, 593-617.

Shore, C.N. (1989). Patronage and bureaucracy in complex societies: Social rules and social relations in an Italian university, JASO, XX, 1, 56-73. 